\title{
Food Demand Elasticities, Price Changes and Calorie Availability of Households in the Western Province of Sri Lanka
}

\author{
S.A.N. Nirmali and J.C. Edirisinghe *
}

\begin{abstract}
This study aimed to investigate the responsiveness of household demand in Western Province for rice (samba), dhal, bread, chicken, coconut, milk powder and sugar. The research finds demand for these foods with the changes in price and expenditure using the linear approximation of the strict Almost Ideal Demand System (LA/AIDS) estimated using the Seemingly Unrelated Regression Procedure (SURE). The data used were from the household income and expenditure survey, 2006/07. All food items were found to be price inelastic while they had a positive expenditure elasticity which is less than unity except bread. Simulations show that the calorie availability of the household declines with most of the food products and in the light of expected food price increases in the world; this will have a marked impact on food security and nutrition security of households in the Western Province.
\end{abstract}

\section{Introduction}

Rising prices have many implications for food and nutritional security especially, in developing nations, both at household and at country levels. As many of the world's poorest spend a lions' share of their incomes on food, rising prices of food have strong implications in the short as well as long run. With the inability to purchase foods when the prices soar, undernourishment raises diseases and mortality, and lowers productivity. Further, it can have lifelong effects on children. Apart from that, rising food prices limits spending on other essentials, such as education and healthcare. The reasons for price hikes in developing countries are said to be inadequate supply, and stagnating low productivity in agriculture, a deteriorating natural resource base, and weak rural and agricultural infrastructure and markets (IFAD, 2011).

Sri Lanka has long been recognized as a country that fared well in terms of education, health and other basic needs despite having a relatively

\footnotetext{
* Authors are, respectively, Final Year Student and Senior Lecturer, Department of Agribusiness Management, Faculty of Agriculture and Plantation Management, Wayamba University of Sri Lanka, Sri Lanka.
} 
low per capita income. However, the food security and nutrition security situation is still poor in Sri Lanka. The country is classified as a middle income food deficit country and food availability depends predominantly on rice production and marketing. Further, poverty remains high and widespread (Anon, 2007). However, the 2009/10 Household expenditure survey reveals, that poverty levels have gone down to $8.9 \%$, though there are disparities regional wise (DCS , 2011) Though poverty rates have gone down, nutrition status is of concern. According to the 2006/07 Sri Lanka demographic and health survey, nutritional states of children less than five years and adults are poor. The prevalence of stunting in children under five years of age was $13.5 \%$, that of wasting $14 \%$ and of underweight $29.4 \%$ chronic energy deficiency. Also in adult group the prevalence of chronic energy deficiency which is more than $33 \%$ in women and nearly $37 \%$ in men (Department of Census and Statistics, 2007).

Human beings need energy to maintain regular body functions. A calorie is a measure of how much energy that protein, carbohydrates, and fat can supply to the human body. The number of calories in food is a measure of how much potential energy that food provides for human body functions. (Anon, 2011a). Therefore, the level of calorie intake by an individual should be adequate to maintain these body functions within his/her life time. Allocations of the food nutrients and the response of the household nutrient intake, changes with food prices and income (Mark and Mark, 1986). High prevalence of under nutrition limits work output, productivity and incomegenerating ability (Anon, 2011b). Nevertheless, empirical evidence of relationship between food price fluctuations and food security is meager and unclear (Myers, 2006). Therefore, investigation of changes in food prices on changes in food consumption and its effect on calorie intake is important. This research takes up this issue and investigates the changes in food consumption and calorie intake due to changes in prices from a sample of households in Western Province in Sri Lanka. Although, the poverty Head Count Index (HCI) is low in the Western Province, the second largest share of poor population is found in it (Department of Census and Statistics, 2007). Further, Department of Census and Statistics (2008) states Persons in Urban sector of Sri Lanka and highly urbanized Western province consume less dietary energy despite their minimum poverty HCI. Further it is revealed that the daily energy consumption of $65 \%$ of the urban population is less than the level of $2030 \mathrm{kcal}$ per person. Comparatively very high dietary energy consumption is reported by all the Estate sector persons regardless of their poverty status. 


\section{Methodology}

\section{Almost Ideal Demand System Model}

There have been many functional forms to model demand systems and the most important and in current use are the Rotterdam model and the translog model. Deaton and Muellbauer, (1980) proposed an alternative model which has considerable advantages over both of these, called the Almost Ideal Demand System (AIDS). This AIDS model gives an arbitrary first-order approximation to any demand system; it satisfies the axioms of choice exactly; it aggregates perfectly over consumers without invoking parallel linear Engel curves; it has a functional form which is consistent with known household-budget data; simple to estimate, largely avoiding the need for nonlinear estimation; and it can be used to test the restrictions of homogeneity and symmetry through linear restrictions on fixed parameters (Deaton and Muellbaue, 1980).

The basis for the AIDS approach comes from the minimization of a cost or expenditure function. Here, the budget shares of the various commodities are linearly related to the logarithm of real total expenditure and the logarithms of relative prices (Deaton and Muellbauer, 1980). The true AIDS model is non-linear thus, difficult to estimate. The model estimated in this study is a linear approximation of the AIDS model (LA/AIDS), which is easier to estimate than the non-liner AIDS model (Akinleye and Rahji, 2007). The LA/AIDS model is usually specified as;

$W_{i}=\propto_{i}+\beta_{i} \ln \left(\frac{X}{P_{c}}\right)+\sum_{j=1} \theta_{i j} \ln \left(P_{j}\right)+\sum_{m=1} \gamma_{i m} Z_{i m}+U_{i}$

Where, $W_{i}=$ budget share of $i^{\text {th }}$ food item; $X=$ the total expenditure on all foods per household; $\mathrm{P}_{\mathrm{c}}=$ Price index; $\mathrm{P}_{\mathrm{j}}=$ Prices of foods $j ; \mathrm{Z}_{\mathrm{im}}=$ characteristics in household head; $\mathrm{U}_{\mathrm{i}}=$ error team of $\mathrm{i}^{\text {th }}$ food equation.

The parameter $\alpha_{i}$ represents the average value of the budget share in the absence of price and income effects. The parameters $\beta_{\mathrm{i}}$ and $\theta_{\mathrm{ij}}$ represent the effects on the expenditure share of good $i$ of a 1 per cent change in real income and price of good $j$ respectively. To avoid nonlinearity, $\ln P_{c}$ can be approximated by the logarithm of the Stone's price index (Akinleye and Rahji, 2007);

$\ln P_{c}=\sum_{j} \bar{W}_{J} \ln P_{j}$

Where, $\bar{W}_{J}=$ the mean budget share of food item $j$. 
Because market prices of commodities were not collected in the survey, unit values (expenditure/quantities) were used in calculations. Deaton (1988) argues that unit values cannot be a direct substitute for market prices in demand analysis. This is because bias is likely to result as a consequence of both quality effects and measurement error. However, he identified the usefulness of unit values in the absence of price data. Properties of a demand function, which can be tested or used to restrict an empirical demand system include: aggregation, symmetry of cross price derivatives, and homogeneity of degree zero in prices and total expenditure, and their compensated price responses form a negative semi definite matrix. Therefore, to account for these, following set of restrictions were applied in estimating the LA/AIDS model (Taljaard et al., 2004).

Adding-up restrictions:

$\sum_{i=1} \alpha_{i}=1 ; \sum_{i=1}^{k} \beta_{i}=0$;

$\sum_{i=1} \theta_{i j}=1 ; \sum_{i=1} \gamma_{i m}=0$

Homogeneity restriction:

$\sum_{j} \theta_{i j}=0$

Symmetry restriction:

$\theta_{i j}=\theta_{j i}$

Elasticity

Marshallian own-price elasticity $\left(\varepsilon_{i i}\right)$ of food item $i$ is calculated as;

$\varepsilon_{i i}=-1+\frac{\theta_{i i}}{W_{i}}-\beta_{i}$

Expenditure elasticity $\left(\eta_{i}\right)$ of food item $i$ can be calculated as;

$\eta_{i}=\frac{\beta_{i}}{w_{i}}+1$

Because the LA/AIDS model is a system of equations representing $i$ equations relating to each food, use of Ordinary Least Squares (OLS) may create bias as there may be relationship among error terms of each equation. A Seemingly Unrelated Regressions (SURE) was used because it takes the correlation of errors into account. However, there are many other methods to 
estimate LA/AIDS model as well, viz., single-equation double-log method, system of equation, S-branch model or almost complete system, and the indirect Frisch method (Orbeta and Alaba, 1998). The error term $U \equiv\left[U_{1}+\right.$ $\left.U_{2}+\cdots, U_{k}\right]$ in the system of equations depicted in [1] is assumed to have a multivariate normal distribution with a covariance matrix $\sum$ but adding up requires it to be singular. Due to this reason one of the $\mathrm{K}$ demand equations needs to be dropped from the system and the remaining (K-1) equations are estimated by maximum likelihood method (Poi, 2002). Elasticities were calculated by using estimated parameters of the model. One of the objectives of the study was to assess the changes in calorie availability due to changes in prices. We achieved this objective by projecting the changes in consumption using the price elasticities calculated using (6) above and relating it to calorie availability of each food item obtained from the 'Food Exchange Lists' published by the US department of Health and Human Services (2011). This procedure is similar to that was used by Quisumbing (1985) in his study on estimating food sector policies on food demand. Others calculated price and income elasticity of demand for calories by taking weighted average of food demand elasticities using calories as weights (Sahn, 1988; Huang 1996; Akinleye, and Rahji, 2007). This study does not estimate elasticity of demand for calories, but rather simulate the changes in calories with the expected changes in consumption when prices change.

\section{Data Source}

Data required for the empirical analysis was taken from the household income and expenditure survey 2006/07 (HIES) conducted by Department of Census and Statistics in Sri Lanka. This provided information on household income and expenditure, levels and changes in living conditions of the people, consumption patterns, and various other socio economic indicators. The sample size of the full survey is 25,000 household that cover all districts in Sri Lanka. The estimation sample consisted of 4,633 households from Colombo, Gampaha and Kalutara districts. The survey has been conducted over a period of 12 month time recording weekly consumption of foods. Average household expenditure on food is Rs. 5,848 per month for Sri Lanka and the ratio of expenditure on food to total expenditure (food ratio) is $44.5 \%$. Survey results revealed that the mean household income per month is Rs. 12,803. Average monthly household expenditure on food \& drink and mean household income in western province is given in Table 1. 
Table 1: Average monthly household expenditure on food \& drink and mean household income $(2006 / 07)$

\begin{tabular}{lcc}
\hline District & $\begin{array}{c}\text { Expenditure on food \& drink } \\
\text { (Rs.) }\end{array}$ & $\begin{array}{c}\text { Mean household } \\
\text { income(Rs.) }\end{array}$ \\
\hline Colombo & 10,795 & 42,825 \\
Gampaha & 9,487 & 29,038 \\
Kalutara & 9,484 & 27,721 \\
\hline
\end{tabular}

Source: Household income and expenditure survey, 2006/07

This study considered eight food items which are common in consumer's basket: [1] Rice (Samba), [2] wheat flour, [3] dhal, [4] bread, [5] chicken, [6] coconut, [7] milk powder, and [8] sugar. The model controls for household characteristics by incorporating covariates: age and sex of the household head. STATA (version 8) was used to estimate coefficients of the LA/AIDS model using SURE method.

\section{Results and Discussion}

\section{Almost Ideal Demand System Model}

The results of the SURE estimation of the LA/AIDS model are recorded in Table 2. Most of the coefficients of independent variables are significant at the $95 \%$ confidence level. The gender of the household head and the age is included as preference proxies in order to control the regression for preferences of households.

Table 2: Parameters estimated from the LA/AIDS model

\begin{tabular}{|c|c|c|c|c|c|c|c|}
\hline \multirow[t]{2}{*}{ Variable } & \multicolumn{7}{|c|}{ Coefficient } \\
\hline & W1 & W3 & W4 & W5 & W6 & W7 & W8 \\
\hline $\operatorname{lnp} 1$ & $1.03 \times 10^{-3} *$ & $-2.23 \times 10^{-4} *$ & $-9.02 \times 10^{-4} *$ & $-3.12 \times 10^{-3} *$ & $-2.61 \times 10^{-4} *$ & $-3.57 \times 10^{-3} *$ & $-1.34 \times 10^{-4} *$ \\
\hline $\operatorname{lnp} 2$ & $-2.23 \times 10^{-4} *$ & $1.01 \times 10^{-3} *$ & $-9.62 \times 10^{-3} *$ & $-2.95 \times 10^{-3} *$ & $2.15 \times 10^{-2} *$ & $2.77 \times 10^{-3} *$ & $-2.96 \times 10^{-3} *$ \\
\hline $\operatorname{lnp} 3$ & $-9.02 \times 10^{-4} *$ & $4.37 \times 10^{-3} *$ & $-1.06 \times 10^{-2} *$ & $-1.04 \times 10^{-4} *$ & $3.51 \times 10^{-3} *$ & $5.61 \times 10^{-3} *$ & $2.44 \times 10^{-3} *$ \\
\hline $\operatorname{lnp} 4$ & $-3.12 \times 10^{-3} *$ & $-1.06 \times 10^{-2} *$ & $7.78 \times 10^{-3}$ & $-2.19 \times 10^{-3} *$ & $-3.37 \times 10^{-7} *$ & $-7.43 \times 10^{-3} *$ & $-1.33 \times 10^{-2} *$ \\
\hline $\operatorname{lnp} 5$ & $-2.61 \times 10^{-4 *} *$ & $-103 \times 10^{-3} *$ & $-2.19 \times 10^{-3} *$ & $8.80 \times 10^{-3}$ & $-1.83 \times 10^{-3} *$ & $-3.04 \times 10^{-5} *$ & $-2.14 \times 10^{-3} *$ \\
\hline $\operatorname{lnp} 6$ & $-3.57 \times 10^{-3} *$ & $3.51 \times 10^{-3} *$ & $-3.37 \times 10^{-3} *$ & $-8.10 \times 10^{-3 *}$ & $3.03 \times 10^{-2} *$ & $-4.14 \times 10^{-4 *}$ & $7.86 \times 10^{-3} *$ \\
\hline $\operatorname{lnp} 7$ & $-1.34 \times 10^{-3} *$ & $5.61 \times 10^{-4} *$ & $-7.43 \times 10^{-3} *$ & $2.38 \times 10^{-4} *$ & $-4.14 \times 10^{-4} *$ & $8.30 \times 10^{-3} *$ & $-1.70 \times 10^{-4} *$ \\
\hline $\operatorname{lnp} 8$ & $-9.00 \times 10^{-3} *$ & $2.44 \times 10^{-3} *$ & $-1.33 \times 10^{-2} *$ & $1.06 \times 10^{-3} *$ & $1.77 \times 10^{-4} *$ & $-1.70 \times 10^{-3} *$ & $9.65 \times 10^{-3} *$ \\
\hline $\ln x / p$ & $-6.50 \times 10^{-5 *}$ & $-3.85 \times 10^{-4} *$ & $3.32 \times 10^{-3} *$ & $-1.14 \times 10^{-3} *$ & $-1.28 \times 10^{-3} *$ & $-6.12 \times 10^{-4} *$ & $-6.98 \times 10^{-4} *$ \\
\hline Income & $3.10 \times 10^{-8} *$ & $1.00 \times 10^{-9} *$ & $-1.00 \times 10^{-8} *$ & $-5.00 \times 10^{-9} *$ & $2.00 \times 10^{-9} *$ & $-6.00 \times 10^{-9} *$ & $-8.00 \times 10^{-9} *$ \\
\hline Sex & $1.28 \times 10^{-3} *$ & $1.06 \times 10^{-3 *}$ & $-1.30 \times 10^{-2} *$ & $147 \times 10^{-3 *}$ & $2.24 \times 10^{-5 *}$ & $7.60 \times 10^{-3} *$ & $-1.96 \times 10^{-4 *}$ \\
\hline Age & $-1.11 \times 10^{-4} *$ & $-6.25 \times 10^{-5 *}$ & $7.50 \times 10^{-4 *}$ & $1.75 \times 10^{-5 *}$ & $-4.67 \times 10^{-4} *$ & $-1.48 \times 10^{-4} *$ & $-3.66 \times 10^{-5 *}$ \\
\hline Constant & $4.70 \times 10^{-2} *$ & $3.98 \times 10^{-2} *$ & $5.37 \times 10^{-1}$ & $2.61 \times 10^{-2} *$ & $1.55 \times 10^{-5 *}$ & $1.01 \times 10^{-1} *$ & $6.49 \times 10^{-2 *}$ \\
\hline
\end{tabular}

* Significant at $5 \%$ level, $\mathrm{W}_{\mathrm{i}}$ is the budget share of the $\mathrm{i}^{\text {th }}$ food item $\quad(\mathrm{i}=1, \ldots .7)$ except wheat flour. $\ln \mathrm{P}_{\mathrm{i}}$ is the $\log$ price of $\mathrm{i}^{\text {th }}$ food item. $(\mathrm{i}=1,2 \ldots 8)$.

All prices returned negative signs. The expenditure coefficients were negative, indicating the necessity of those food items. Also the budget share of rice (samba), dhal, and coconut had positive effect with income. Average budget share for each good is given in Figure 1. 
Figure1: Average budget share of food items

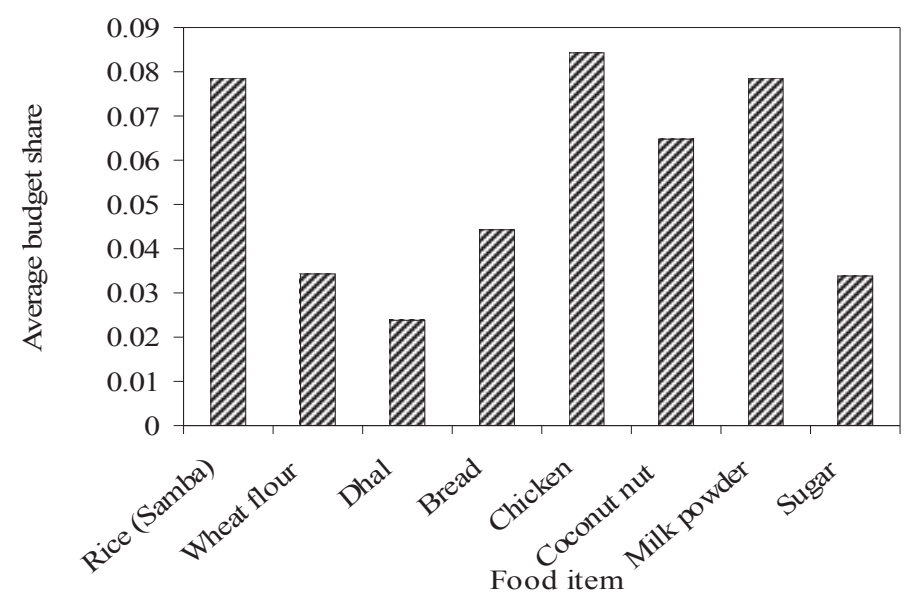

\section{Elasticity Estimates}

The own price and expenditure elasticity are given in Table 3. The own price elasticities were negative for all food items and greater than zero and less than one, indicating inelasticity of demand in these goods. It reflected the quantity demand changes by a smaller percentage than price. This is in line with food demand elasticities in Sri Lanka (Sahn, 1988). The expenditure elasticity of all foods was positive and therefore, these are normal goods. Expenditure elasticity for bread was greater than one indicating that demand for bread is more responsive to changes in consumer expenditure while for rice (samba), dhal, chicken, coconut, milk powder and sugar, it is less than one. The high expenditure elasticity value for bread was reported by Sahn (1988) for the estate sector in Sri Lanka but according to that study, it was less than unity in the case of urban consumers.

Table 3: Own price and expenditure elasticities

\begin{tabular}{lcc}
\hline Food & Own price elasticity & Expenditure elasticity \\
\hline Rice (Samba) & -0.71022 & 0.998174 \\
Dhal & -0.89677 & 0.990956 \\
Bread & -0.85506 & 1.006046 \\
Chicken & -0.74791 & 0.99673 \\
Coconut nut & -0.77402 & 0.990503 \\
Milk powder & -0.91959 & 0.994108 \\
Sugar & -0.86717 & 0.990441 \\
\hline
\end{tabular}


These elasticity figures are calculated for data pertaining to the year 2006. Hence, a projection was carried out to see how the changes in prices from 2006 to 2010 had impacted on consumption of these goods and the impact on calorie availability at household level which is reported in Table 4. The procedure in doing this was as follows. Because all estimates refer to the year 2006, to check whether the real prices have changed from 2006 to 2010, all prices were deflated. The deflated prices of 2006 and 2010 were compared to verify whether the prices have increased, reduced or remained constant. Then, using calculated elasticity values, quantities are predicted for these changes in prices. The level of calorie availability of each food item is obtained from 'food exchange lists', published by the US Department of Health and Human Services (2011). Changes in calorie availability is calculated using this information and the changes in quantities consumed calculated using the elasticities and the real price changes as discussed previously. Table 5 exhibits simulations in changes in quantity consumed and calorie availability.

This result reflected changing price of food items directly influence to the quantities of foods and availability of calories. Calorie availability reduced with price increases except in chicken and sugar. This is because there is no evidence of increases in real prices of these two goods from 2006 to 2010.

Table 4: Percentage change in quantity and calorie availability of food items-2006 and 2010

\begin{tabular}{lcccccr}
\hline \multicolumn{1}{c}{ Food } & $\begin{array}{c}\text { Average } \\
\text { Price } \\
\mathbf{2 0 0 6} \\
\text { (Rs.) }\end{array}$ & $\begin{array}{c}\text { Real } \\
\text { price } \\
\mathbf{2 0 0 6}\end{array}$ & $\begin{array}{c}\text { Average } \\
\text { Price 2010 } \\
\text { (Rs.) }\end{array}$ & $\begin{array}{c}\text { Real } \\
\text { price } \\
\mathbf{2 0 1 0}\end{array}$ & $\Delta$ quantity\% & $\Delta$ calorie\% \\
\hline Rice(Samba) & 40.96 & 0.29 & 67.88 & 0.31 & -0.07 & -0.12 \\
Dhal & 87.27 & 0.62 & 145.69 & 0.66 & -0.03 & -0.02 \\
Bread & 19.67 & 0.14 & 50.00 & 0.23 & -10.68 & -21.37 \\
Chicken & 264.67 & 1.88 & 350.00 & 1.60 & 0.14 & 0.25 \\
Coconut nut & 19.95 & 0.14 & 34.17 & 0.16 & -0.36 & -1.07 \\
Milk powder & 411.14 & 2.92 & 645.00 & 2.94 & -0.01 & -0.02 \\
Sugar & 61.18 & 0.43 & 94.29 & 0.43 & 0.01 & 0.04 \\
\hline
\end{tabular}

* Note: Prices are in unit values (expenditure/quantities). In the case of Rice, Dhal, Chicken, and Sugar, it is in Rs $/ \mathrm{kg}$, in the case of bread it is Rs $/ 450 \mathrm{~g}$ and in the case of coconut, it is Rs/nut

Prices fluctuate within the year as well as between years due to various reasons. Even though inflation may go down technically, food prices will still rise. For example, the revision of import duty pertaining to key food items during the year, the decline in average prices of certain domestic agricultural products due to increases in domestic supply conditions are some of the reasons for price fluctuation (Annual Report of Central Bank, 2010). In such situations, quantities and calorie availability can change. To take this 
uncertainty in prices to account, a simulation is made with increasing and reducing prices by $10 \%, 20 \%$ and $30 \%$. The results are reported in Table 5 . The changes in the calorie available are at household level because of the unavailability of individual consumption. Also, this research has not considered the impact on children and adults separately and therefore, are research questions to be explored with a richer data set than the present. Based on the results in Table 5, household calorie availability is largely affected by the price changes in Dhal.

Table 5: Simulations in changes in quantity consumed and calorie availability

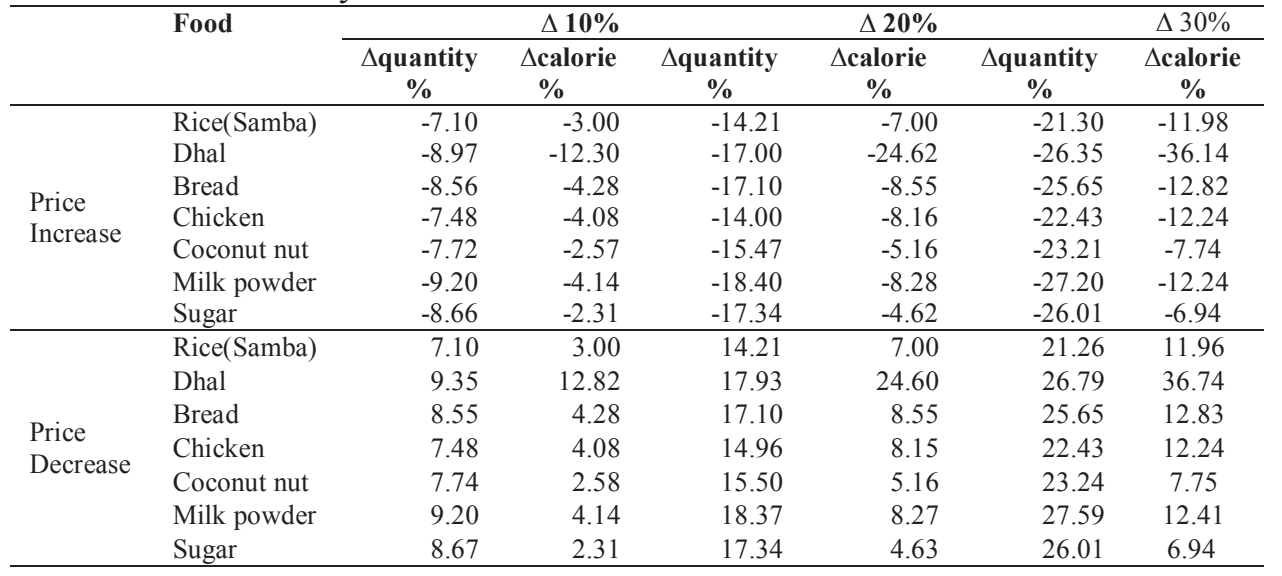

\section{Conclusions}

A LA/AIDS model was applied for household data from the Western Province of Sri Lanka to model household demand for eight food items and investigated the impacts of calorie changes due to the change of food prices. Estimated price and expenditure elasticities were used to compute the variations in quantity demanded and calorie availability.

All food items had positive expenditure elasticity and negative own price elasticity. All eight foods items were inelastic or less responsiveness to price changes. Because of the increase in real prices, the change in quantity and calorie availability of rice (samba), dhal, bread, coconut and milk powder have reduced. Real price of chicken has reduced from 2006 to 2010. Therefore, consumption shows an increase. Real price of sugar has not changed, but the percentage change in consumption show an increase.

The eight food items selected are some of the most important and commonly consumed in an average consumers' diet. The results suggest that changes in prices of these foods have a marked impact on calorie availability 
at the household level. Therefore, expected price increases in future will have a discernible impact on the food security of households.

This study could be further improved if the changes in calorie availability were calculated for different income strata and based on per capita consumption of each commodity between different income strata in Sri Lanka. This would shed light on policy options as distributional effects are taken into consideration. Future research should address such issues.

\section{Acknowledgements}

Authors would like express their gratitude to the staff of the Department of Census and Statistics for their kind corporation in providing data for this study.

\section{References}

Akinleye, S.O. and M.A.Y. Rahji (2007). Nutrient Elasticities among Nigerian Households Differentiated by Income. Agrekon, 46;274-288.

Annual Report (2010). Central Bank of Colombo, Sri Lanka.

Anon (2007). Sri Lanka Integrated Food Security and Humanitarian Phase Classification, viewed $12^{\text {th }} \quad$ January, 2011, $<$ https://docs.google.com/viewer?a=v\&q= cache:r70uxUJjYcJ:www. ipcinfo.org/attachments/Ex_Brief_IPC_Sri_Lanka_June2007>.

Anon (2011a). What are Calories? Viewed $3^{\text {rd }}$ January, 2011, $<$ http://www.mamashealth.com/ nutrition/calories.asp $>$.

Anon (2011b). Food and Agriculture Organization. Nutrition Country Profiles: Sri Lanka, viewed $6^{\text {th }}$ April, 2011, $<$ http://www.fao.org/ag/agn/nutrition/lka_en.stm>.

Deaton, A.S. (1988). Quality, Quantity and Spatial Variation of Rice. American Economic Review, 78:418-430.

Deaton, A.S. and J. Muellbauer (1980). An Almost Ideal Demand System. The American Economic Review, 70(3):312-326.

Deaton, A.S. and J. Muellbauer (1980). Economics and Consumer Behavior. Cambridge: Cambridge University Press. 
Department of Census and Statistics (2007). Household Income and Expenditure Survey (2006/07), Colombo. Sri Lanka.

Department of Census and Statistics (2007). Sri Lanka Demographic and Health Survey. Colombo, Sri Lanka.

Department of Census and Statistics (2008). Sri Lanka Demographic and Health Survey. Colombo, Sri Lanka.

Department of Census and Statistics (2011). Household Income and Expenditure Survey (2009/10), Colombo. Sri Lanka.

Huang K.S. (1996). Nutrient Demand Elasticities in a Complete Food Demand System. American Journal of Agricultural Economics, 78:21-29.

IFAD (2011). Higher and Volatile Food Prices and Poor Rural People, viewed $8^{\text {th }}$ September, 2011, <http://www.ifad.org/operations/food/>.

Mark, M.P. and R.R. Mark (1986). Agricultural Prices, Food Consumption, the Health and Productivity of Indonesian Farmers. In Agricultural Household Models: Extension, Applications and Policy. I. Singh, L. Squire and J. Strauss (eds.). London: The John Hopkins University Press.

Myers, R.J. (2006). On the Costs of Food Price Fluctuations in Low-income Countries. Food Policy, 31:288-301.

Orbeta, A.C., and Jr. M.M. Alba (1998). Simulating the Impact of Macroeconomic Policy Changes on Macronutrient Availability in Households. Journal of Philippine Development, 45(1):181-227.

Poi, B.P. (2002). From the Help Desk: Demand System Estimation. The Stata Journal 2(4): 403-410.

Taljaard P.R., Z.G. Alemu and H.D. Van Schalkwyk (2004). The Demand for Meat in South Africa: An Almost Ideal Estimation. Agrekon, 43:430443.

Quisumbing, A. (1985). Estimating the Distributional Impact of Food Market Intervention on Policies on Nutrition. PhD Dissertation, University of Philippines. 
26

Sahn, D.E., (1988). The Effect of Price and Income Changes on Food-energy Intake in Sri Lanka. Economic Development and Cultural Change, 36(2):316-340.

US Department of Health and Human Services (2011). Food Exchange Lists. Viewed $10^{\text {th }} \quad$ September, 2011, <http://www.nhlbi.nih.gov/ health/public/heart/obesity/lose_wt/fd_exch.htm>. 